\title{
Ni(II) complex with sarcosine derived from in situ generated ligand: structural, spectroscopic, and DFT studies
}

\author{
Hanna Fałtynowicz ${ }^{1}$ Marek Daszkiewicz ${ }^{2} \cdot$ Rafał Wysokiński $^{1} \cdot$ Anna Adach $^{3}$. \\ Maria Cieślak-Golonka ${ }^{1}$
}

Received: 26 June 2015/Accepted: 29 June 2015/Published online: 21 July 2015

(c) The Author(s) 2015. This article is published with open access at Springerlink.com

\begin{abstract}
Nickel(II) complex with sarcosine [Ni(sar $)_{2}$ $\left.\left(\mathrm{H}_{2} \mathrm{O}\right)_{2}\right](\mathbf{1})$ has been obtained as a reaction product of a system: $\mathrm{Ni}(\mathrm{II}) \mathrm{Cl}_{2}-1$-methylhydantoin. Basic hydrolysis of the organic substrate leads to in situ formation of sarcosine ligand, which coordinates to the metal ion. The isolated complex has been characterized by means of single crystal $\mathrm{X}$-ray diffraction and spectroscopic studies (IR, Raman, and NIR-UV-Vis) supported with DFT calculations. Single crystal X-ray diffraction revealed that the nickel environment in $\left[\mathrm{NiN}_{2} \mathrm{O}_{4}\right]$ chromophore exhibited the geometry of a tetragonally elongated octahedron. Hydrogen bonds create two chain patterns which propagate along the main crystallographic directions $a$ and $b$. It leads to the formation of a 2D network. Electronic spectra analysis showed that the nickel surroundings can be described as pseudooctahedral in solution and tetragonal in the solid state. Based on the calculated 10Dq parameter $\left(10,990 \mathrm{~cm}^{-1}\right)$, sarcosine ligand was located in the spectrochemical series close to ammonia. Comprehensive studies of the molecular structure and
\end{abstract}

Dedicated to Professor Magdolna Hargittai on the occasion of her 70th birthday.

Electronic supplementary material The online version of this article (doi:10.1007/s11224-015-0631-7) contains supplementary material, which is available to authorized users.

Rafał Wysokiński

rafal.wysokinski@pwr.edu.pl

1 Faculty of Chemistry, Wrocław University of Technology, Wybrzeże Wyspiańskiego 27, 50-370 Wrocław, Poland

2 Institute of Low Temperature and Structure Research, Polish Academy of Sciences, Okólna 2, P.O. Box 1410, 50-950 Wrocław, Poland

3 Institute of Chemistry, Jan Kochanowski University, Świętokrzyska 15G, 25-406 Kielce, Poland vibrational spectra of the title complex have been performed using UPBE0, unrestricted density functional method. The clear-cut assignment of the bands in FT-IR and Raman spectra of studied complex has been made on the basis of the calculated potential energy distribution. The Ni-L(sarcosine) stretching vibrations were assigned in Raman spectrum to the medium intensity band at $442 \mathrm{~cm}^{-1}$.

Keywords Nickel complex · Sarcosine ligand . 1-Methylhydantoin hydrolysis - Spectrochemical series of ligands - Spectroscopic method - DFT calculations

\section{Introduction}

Sarcosine (N-methylglycine) (Fig. 1) is an $\alpha$-amino acid occurring in various living organisms as an intermediate in amino acid metabolism [1] and as a component of peptides, e.g., actinomycines [2]. Additionally, it can potentially serve as a liposome cryoprotectant and as a drug in the treatment for schizophrenia [3, 4].

In recent years, various sarcosine adducts, salts, and metal complexes have been prepared. The latter have been studied in order to understand the mechanism of interactions between amino acids and metal ions found in biological systems, i.e., $\mathrm{Ca}, \mathrm{Zn}, \mathrm{Cu}$ [5-7]. They can serve as potential laser materials [8] as well as anticancer drugs [9]. In all cases, they have been prepared using sarcosine as a starting reagent.

Sarcosine can also be a product of acid or basic hydrolysis of 1-methylhydantoin (Fig. 1). Hydantoin and its derivatives at moderate temperature and $\mathrm{pH}$ form complexes with metal ions [10-13]. However, when elevated temperature and extreme $\mathrm{pH}$ are applied, hydantoins hydrolyze, forming in the most cases, amino acids [14]. 
Fig. 1 Scheme of the hydrolysis of 1-methylhydantoin, which results in a sarcosine as the final products

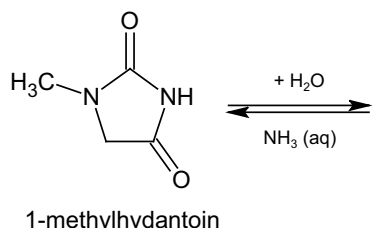

1-methylhydantoin

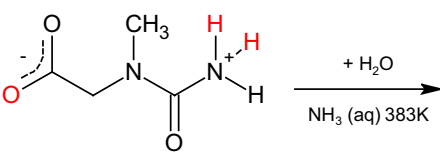

1-methylhydantoic acid

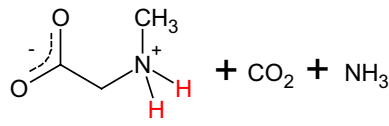

1-methylglycine (sarcosine)
Such in situ formed amino acids could subsequently coordinate to metal ions [15].

In the present work, the complex $\left[\mathrm{Ni}(\mathrm{sar})_{2}\left(\mathrm{H}_{2} \mathrm{O}\right)_{2}\right](\mathbf{1})$ has been obtained as a result of the reaction between 1-methylhydantoin and nickel(II) salt. At elevated temperature and $\mathrm{pH}, 1-$-methylhydantoin hydrolyzed resulting in a sarcosine, ammonia, and carbon dioxide as the final products (Fig. 1) [14]. Then, in situ produced ligand was coordinated by metal ion forming (1). Incomplete structure of (1) was known earlier [16]. Here, it has been characterized in detail using both experimental (X-ray diffraction, IR, Raman, and electronic spectroscopy) and theoretical (DFT) methods. To the best of our knowledge, this is the first example of a sarcosine complex synthesized from an organic substrate other than sarcosine itself. It was found that crystals of (1) obtained by this "indirect" method are of better quality than those created from sarcosine as a starting reagent. For example, they do not show tendency to twinning.

\section{Experimental}

\section{Preparation}

1-Methylhydantoin was purchased from Sigma-Aldrich, while nickel(II) chloride (anhyd.) and ammonia solution (25\%) were from POCH S.A. and used without further purification. Nickel(II) chloride $(0.5 \mathrm{mmol})$ and 1-methylhydantoin $(1 \mathrm{mmol})$ were dissolved in $10 \mathrm{~cm}^{3}$ of ammonia solution and then heated in the solvothermal conditions at $383 \mathrm{~K}$ for $15 \mathrm{~h}$. After cooling down, the resultant solution was left to slow evaporation in the air. After 1 month, blue single crystals of (1) were obtained.

\section{Elemental analysis}

Elemental analysis was carried out using elemental analyzer Vario El III (Elementar). Anal. Calc. for $\mathrm{C}_{6} \mathrm{H}_{16} \mathrm{~N}_{2} \mathrm{NiO}_{6}(\%)$ : C, 26.60; N, 10.34; H, 5.95. Found: C, 26.60; N, 10.31; H, 5.98 .

\section{X-ray diffraction}

X-ray diffraction data were collected on a KUMA Diffraction KM-4 four-circle single crystal diffractometer equipped with a CCD detector using graphite-monochromatized $\mathrm{MoK}_{\alpha}$ radiation $(\alpha=0.71073 \AA$ ). Experiment was carried out at $295 \mathrm{~K}$. The raw data were treated with the CrysAlis Data Reduction Program (version 1.172.33.42) taking into account an absorption correction. The intensities of the reflection were corrected for Lorentz and polarization effects. The crystal structure was solved by direct methods [17] and refined by full-matrix least-squares method using SHELXL-2013 and ShelXle programs [17, 18] (Table 1). Non-hydrogen atoms were refined using anisotropic displacement parameters. H-atoms of the sarcosine anion were visible on the Fourier difference maps, but placed by geometry and allowed to refine "riding on" the parent atom. The positions of $\mathrm{H}$-atoms of the water molecule and $\mathrm{NH}$ group were refined without constraints, but $\mathrm{U}_{\text {iso }}(\mathrm{H})=1.5 \mathrm{U}_{\mathrm{eq}}(\mathrm{O})$ and $\mathrm{U}_{\mathrm{iso}}(\mathrm{H})=1.2 \mathrm{U}_{\mathrm{eq}}(\mathrm{N})$.

\section{NIR-UV-Vis electronic, IR, and Raman spectroscopy}

Electronic spectra of solid state (reflectance) and water solution (absorbance) $\left(c=6.9410^{-3} \mathrm{M}\right)$ were recorded on Cary 500 Scan (Varian) UV-Vis-NIR spectrophotometer in the range of $7500-35,000 \mathrm{~cm}^{-1}$, with resolution of $10 \mathrm{~cm}^{-1}$. To obtain accurate band positions, the spectra were analyzed using variable digital filter method [19, 20] with the following parameters: a real number determining the degree of resolution enhancement, $\alpha=200$; the integer number determining the filter width, $N=10$; the increment between points $($ step $)=100 \mathrm{~cm}^{-1}$. Crystal field parameters were calculated based on the known equations for $3 \mathrm{~d}^{8}$ configuration with $\mathrm{O}_{h}$ and $\mathrm{D}_{4 \mathrm{~h}}$ symmetry of the metal surrounding [21, 22].

The FT-IR spectrum was measured on Bruker IFS $113 \mathrm{~V}$ spectrometer in the region of $4000-400 \mathrm{~cm}^{-1}$ with resolution of $2 \mathrm{~cm}^{-1}$ using $\mathrm{KBr}$ pellets. The far-infrared spectrum, in the range of $600-50 \mathrm{~cm}^{-1}$, was recorded on FT-IR Bruker IFS 66/S spectrometer with resolution of $2 \mathrm{~cm}^{-1}$ using Nujol mull technique. The FT-Raman spectrum, in the range of $4000-50 \mathrm{~cm}^{-1}$, was measured on Bruker MultiRAM spectrometer equipped with Nd:YAG laser, emitting radiation at a wavelength of $1064 \mathrm{~nm}$ and liquid nitrogen-cooled germanium detector. The spectrum was recorded with resolution of $2 \mathrm{~cm}^{-1}$. 
Table 1 Crystal data and structure refinement for the $\left[\mathrm{Ni}(\mathrm{sar})_{2}\left(\mathrm{H}_{2} \mathrm{O}\right)_{2}\right]$

\begin{tabular}{|c|c|}
\hline Chemical formula & $\mathrm{C}_{6} \mathrm{H}_{16} \mathrm{~N}_{2} \mathrm{NiO}_{6}$ \\
\hline$M_{\mathrm{r}}$ & 270.92 \\
\hline$a, b, c(\AA)$ & $\begin{array}{l}5.3906(10), 6.5849(15) \\
8.2769(17)\end{array}$ \\
\hline$\alpha, \beta, \gamma(\operatorname{deg})$ & $\begin{array}{c}102.943(18), 96.314 \\
(16), 109.476(18)\end{array}$ \\
\hline$V\left(\AA^{3}\right)$ & $264.45(10)$ \\
\hline$\mu\left(\mathrm{mm}^{-1}\right)$ & 1.85 \\
\hline Crystal size (mm) & $0.42 \times 0.31 \times 0.21$ \\
\hline$T_{\min }, T_{\max }$ & $0.474,0.699$ \\
\hline $\begin{array}{l}\text { No. of measured, independent, and } \\
\text { observed }[I>2 \sigma(I)] \text { reflections }\end{array}$ & $3422,1198,1140$ \\
\hline$R_{\mathrm{int}}$ & 0.033 \\
\hline$(\sin \Theta / \lambda)_{\max }\left(\AA^{-1}\right)$ & 0.649 \\
\hline$R\left[F^{2}>2 \sigma\left(F^{2}\right)\right], w R\left(F^{2}\right), S$ & $0.030,0.064,1.09$ \\
\hline No. of refl./par. & $1198 / 80$ \\
\hline$\left.\Delta\rangle_{\max }, \Delta\right\rangle_{\min }\left(\mathrm{e} \AA^{-3}\right)$ & $0.42,-0.42$ \\
\hline
\end{tabular}

\section{Theoretical study}

The molecular structure of (1) has been fully optimized with unrestricted density functional one-parameter hybrid protocol PBE0 [23-25]. The combined basis sets were used in calculation: the polarized valence double- $\zeta$ basis set D95v(d,p) for nonmetal atoms and for nickel the LanL2DZ effective core potential with conjunct valence basis set [26]. The examined value of total spin, $\hat{\mathrm{S}}^{2}$, was equal to 2.000, which corresponds to a triplet ground-state wave function with no spin contamination [27]. All calculations have been performed using the Gaussian 09 set of programs [28]. Natural charges were obtained by the natural bond orbital (NBO) analysis using version 5.0 of the program [29, 30].

For clear-cut vibrational assignment of the experimental spectra of (1), a normal coordinate analysis was applied. The potential energy distribution (PED) was calculated with the procedure as described earlier [31, 32]. A nonredundant set of 87 internal coordinates has been constructed, as suggested by Fogarasi et al. [33]. PED calculations were performed using the Balga program [34]. The theoretical frequencies above $1510 \mathrm{~cm}^{-1}$ have been scaled.

The theoretical Raman intensities $I_{R}$ were calculated according to the following formula [35-37]:

$I_{i}^{R}=C\left(v_{0}-v_{i}\right)^{4} v_{i}^{-1} B_{i}^{-1} S_{i}$

where $C$ is a constant equal to $10^{-12}, B_{i}$ is the temperature factor represented by the Boltzmann distribution (in this work assumed to be 1 as discussed earlier [37]), $v_{0}$ is the wave number of the laser radiation (in this work, $v_{0}=9398.5 \mathrm{~cm}^{-1}$, which corresponds to a wavelength of the 1064-nm line of a Nd:YAG laser), $v_{i}$ is the wave number of the normal mode $\left(\mathrm{cm}^{-1}\right)$, and $\mathrm{S}_{\mathrm{i}}$ is the computed Raman scattering activity of normal mode $Q_{i}$. The calculated Raman intensities $I_{R}$ presented in Table 6 are given in arbitrary units.

\section{Results and discussion}

Examination of Cambridge Structural Database (CSD) (version 5.34) revealed that the sarcosine moiety may occur in various forms in complexes: an anion, a zwitterion, or a cation and its various forms coordinate in different ways. When anionic form is present, sarcosine forms a bidentate ligand where $\mathrm{N}$ and one of $\mathrm{O}$ atoms are involved in coordination (Fig. 2a) [9, 38-40]. In the case of zwitterion and cationic forms, it acts as mono- [7], bidentate [8] or bridging ligand [5, 41-43], but only carboxylate group binds to metal (Fig. 2b, c). Among metal complexes with sarcosine, cationic form of ligand is the least common. Anionic and zwitterion forms are much more abundant, especially as bidentate or bridging ligands.

\section{Crystal structure}

The structural parameters of (1) were published a long time ago, but the positions of the hydrogen atoms were not reported [16]. Therefore, the crystal structure of this compound is presented de novo in this paper. The complex crystallizes in centrosymmetric space group P-1 of the triclinic symmetry (Table 1). Two sarcosine anions bind through amino and carboxylate groups, and with two water molecules create a distorted octahedral arrangement around the nickel ion (Fig. 3). Half of the (1) molecule lies in the (a)<smiles>[M]C1CC(=O)ON1C</smiles>

(c)<smiles>[M]OC(O)C[NH+](C)C</smiles>

(b)<smiles></smiles><smiles>[M]OC(=O)C[NH2+]C</smiles><smiles>[M]OC(C[NH2+]C)O[M]</smiles><smiles>[M]OC1ON1CC[NH2+]C</smiles><smiles>[M]OC(=O)C[NH2+]C</smiles>

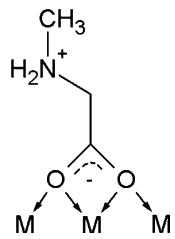

Fig. 2 Forms of sarcosine ligand and types of the coordination in sarcosine metal complexes: a anionic bidentate ligand coordinating by the $\mathrm{N}$ and one of the $\mathrm{O}$ atoms, $\mathbf{b}$ zwitterion mono- or bidentate, sometimes bridging, ligand, $\mathbf{c}$ cationic monodentate ligand 
(a)

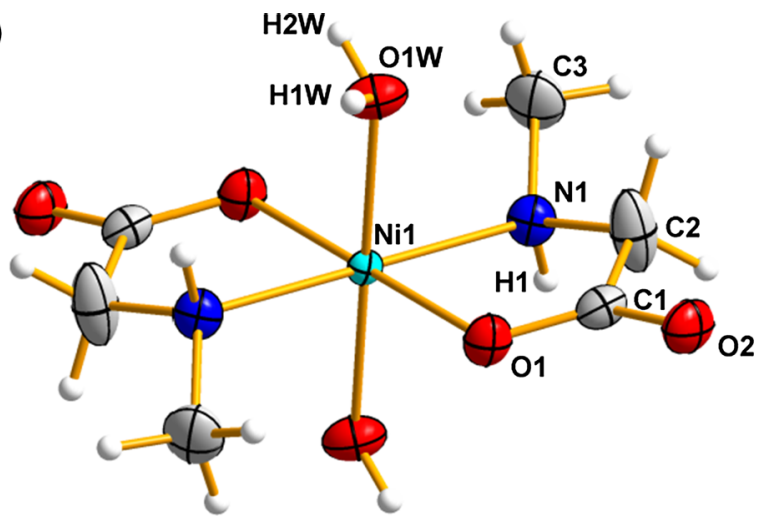

(b)
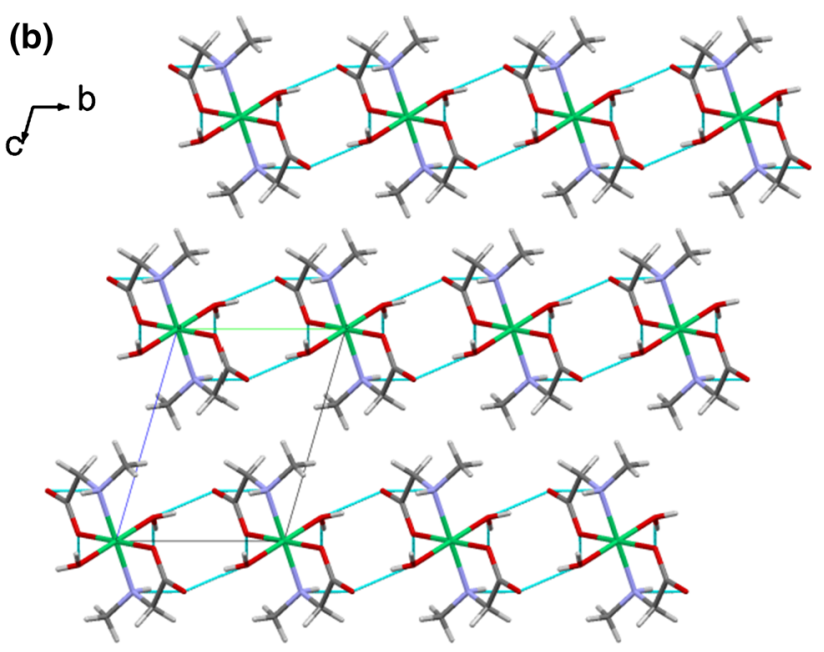

Fig. 3 a Crystal structure of $\left[\mathrm{Ni}(\mathrm{sar})_{2}\left(\mathrm{H}_{2} \mathrm{O}\right)_{2}\right]$. b A view of $\left[\mathrm{Ni}(\mathrm{sar})_{2}\left(\mathrm{H}_{2} \mathrm{O}\right)_{2}\right]$ molecules arranged in layers parallel to $a b$ plane

asymmetric part of the unit cell because the nickel ion lies on the inversion center and therefore (1) possesses $C_{i}$ point group symmetry. Table 2 shows that $\mathrm{Ni}-\mathrm{N} 1$ and $\mathrm{Ni}-\mathrm{O} 1$ bond lengths are significantly shorter than $\mathrm{Ni}-\mathrm{O} 1 \mathrm{~W}$ distances resulting in tetragonal elongation of the nickel(II) octahedron along two Ni-O1W bonds.

In the crystal structure of (1), $\mathrm{N}-\mathrm{H} \cdots \mathrm{O}$ and $\mathrm{O}-\mathrm{H} \cdots \mathrm{O}$ hydrogen bonds join adjacent molecules arranged in a twodimensional network of hydrogen bonds (Fig. 3b, Table 3). The network results in an intersection of the chain patterns which propagate along the main crystallographic directions, $a$ and $b$ (Fig. 4a, b). Each and every chain contains only one type of hydrogen bond, and therefore, these chain patterns described by the unitary graph-set descriptors are the most important one in the crystal structure of (1) [44]. Additionally, ring patterns are also present, two $R_{2}^{2}(8)$ and one $R_{2}^{2}(12)$. Although two rings $R_{2}^{2}(8)$ are described by the same descriptor, they arise from different summation of the elementary graph-set descriptors because different atomic pathways are related to each pattern [45]. The first one results from summation $E_{2}^{0}(5)_{\mathrm{HNNiOH}}+E_{0}^{2}(3)_{\mathrm{OCO}}=R_{2}^{2}(8)$ and the second one from $2 \cdot E_{1}^{1}(4)_{\mathrm{HONiO}}=R_{2}^{2}(8)$ (Fig. 4a). Since two chains $C(6)$ intersect each other at the nickel ion (Fig. 4b), the ring pattern $R_{2}^{2}(12)$ is created. It is connected to the relation $2 \cdot E_{1}^{1}(6)_{\mathrm{HONiOCO}}=R_{2}^{2}(12)$. It is worth noting that $R_{2}^{2}(12)$ ring and the second $R_{2}^{2}(8)$ ring result from doubling $E_{1}^{1}(6)_{\mathrm{HONiOCO}}$ and $E_{1}^{1}(4)_{\mathrm{HONiO}}$ pathways, respectively, due to inversion center located in both ring patterns.

\section{Electronic spectra}

The structural analysis of (1) shows a large angular distortion from the ideal octahedron. It was also confirmed with electronic spectra, measured in the solid state (diffuse reflectance) and water solution (absorbance).

Generally, hexacoordinate octahedral Ni(II) complexes show three broadbands in the NIR, visible and UV regions at 7000-13,000, 11,000-20,000, and 19,000-27,000 $\mathrm{cm}^{-1}$ assigned to the spin-allowed transitions: ${ }^{3} \mathrm{~A}_{2 \mathrm{~g}} \rightarrow{ }^{3} \mathrm{~T}_{2 \mathrm{~g}}\left(v_{1}\right)$, ${ }^{3} \mathrm{~A}_{2 \mathrm{~g}} \rightarrow{ }^{3} \mathrm{~T}_{1 \mathrm{~g}}(\mathrm{~F})\left(v_{2}\right)$, and ${ }^{3} \mathrm{~A}_{2 \mathrm{~g}} \rightarrow{ }^{3} \mathrm{~T}_{1 \mathrm{~g}}(\mathrm{P})\left(v_{3}\right)$, respectively [46]. These transitions are observed in the reflectance spectrum of (1) at $10,450 \mathrm{~cm}^{-1}\left(v_{1}\right), 16,550 \mathrm{~cm}^{-1}\left(v_{2}\right)$, and $25,850 \mathrm{~cm}^{-1}\left(v_{3}\right)$. However, splitting of the highest energy $\mathrm{d}-\mathrm{d}$ band (Fig. 5) indicates distortion of octahedral geometry. The digital filtration analysis of the spectrum revealed that the positions of the bands are typical for complexes of tetragonal $\left(\mathrm{D}_{4 \mathrm{~h}}\right)$ symmetry (Table 4; Fig. 6b). Therefore, further analysis of the solid-state spectrum was carried out assuming tetragonal geometry (vide infra).

In contrast to the reflectance spectrum, band splitting was observed neither in the water solution spectrum nor in its filtered form (Fig. 5). The digital filtration revealed only bands of spin-forbidden transitions $\left({ }^{3} \mathrm{~A}_{2 \mathrm{~g}} \rightarrow{ }^{1} \mathrm{E}_{\mathrm{g}}=\right.$ $13,400 \mathrm{~cm}^{-1},{ }^{3} \mathrm{~A}_{2 \mathrm{~g}} \rightarrow{ }^{1} \mathrm{~T}_{2 \mathrm{~g}}=21,400 \mathrm{~cm}^{-1}$ ). This indicates higher, i.e., pseudooctahedral, symmetry of (1) in solution [11].

On the basis of the band positions, crystal field and Racah B parameters for solid state and solution were calculated (Table 4). Obtained parameter values: $\mathrm{Dq}=1016 \mathrm{~cm}^{-1}$ and $B=795 \mathrm{~cm}^{-1}$ of complex (1) in solution were close to the values found for pseudooctahedral $\mathrm{Ni}(\mathrm{II})$ complexes with $\left[\mathrm{NiN}_{2} \mathrm{O}_{4}\right]$ chromophore $[10,11$, $47,48]$. Crystal field Dq parameter in $\mathrm{D}_{4 \mathrm{~h}}$ symmetry has a slightly different meaning than that in $\mathrm{O}_{\mathrm{h}}$ symmetry, because CF splitting in the former is described by three parameters: Dq, Ds, and Dt [49]. Thus, nephelauxetic parameter $\beta$, which means the ratio of the $B$ value of complex to the $B$ value of free ion $\left(1041 \mathrm{~cm}^{-1}\right.$ [46]), is the only one to be compared. A much higher value for the solid state $(\beta=0.94)$ was found than for solution $(\beta=0.76)$. This means that ionicity of $\mathrm{M}-\mathrm{L}$ bond in solid state is significantly higher than in solution, which was observed earlier for other $\mathrm{Ni}(\mathrm{II})$ complexes [11]. 
Table 2 Selected geometric parameters $(\AA$, deg) for $\left[\mathrm{Ni}(\mathrm{sar})_{2}\left(\mathrm{H}_{2} \mathrm{O}\right)_{2}\right]$

\begin{tabular}{lccllr}
\hline & \multicolumn{1}{l}{ Exp. } & \multicolumn{1}{l}{ Calc. } & & Exp. & Calc. \\
\hline Ni1-O1 & $2.0567(15)$ & 2.002 & C1-O1 & $1.263(3)$ & 1.300 \\
Ni1-N1 & $2.0716(19)$ & 2.081 & C1-O2 & $1.242(2)$ & 1.221 \\
Ni1-O1W & $2.1134(16)$ & 2.224 & N1-C2 & $1.454(3)$ & 1.472 \\
C1-C2 & $1.509(3)$ & 1.544 & N1-C3 & $1.468(3)$ & 1.467 \\
O1-Ni1-O1 & 180.0 & 180.0 & O1 ${ }^{\mathrm{i}}-\mathrm{Ni1}-\mathrm{O} 1 \mathrm{~W}$ & $86.44(7)$ & 75.9 \\
O1-Ni1-N1 & $97.46(6)$ & 98.2 & N1 ${ }^{\mathrm{i}}-\mathrm{Ni1}-\mathrm{O} 1 \mathrm{~W}$ & $89.48(7)$ & 85.8 \\
O1-Ni1-N1 & $82.54(6)$ & 81.8 & N1-Ni1-O1W & $90.52(7)$ & 94.2 \\
N1 $1^{\mathrm{i}-N i 1-N 1}$ & 180.0 & 180.0 & O1W-Ni1-O1W & 180.0 & 180.0 \\
O1-Ni1-O1W & $93.56(7)$ & 104.1 & & & \\
\hline
\end{tabular}

Symmetry code(s): (i) $-x,-y,-z$
Table 3 Selected hydrogen bond parameters ( $\AA$, deg) for $\left[\mathrm{Ni}(\mathrm{sar})_{2}\left(\mathrm{H}_{2} \mathrm{O}\right)_{2}\right]$

\begin{tabular}{lllll}
\hline$D-\mathrm{H} \cdots A$ & $D-\mathrm{H}$ & $\mathrm{H} \cdots A$ & $D \cdots A$ & $D-\mathrm{H} \cdots A$ \\
\hline N1-H1 $\cdots \mathrm{O} 2^{\mathrm{i}}$ & $0.88(3)$ & $2.13(3)$ & $3.000(3)$ & $170(2)$ \\
${\text { O1W-H1W } \cdots O 1^{\mathrm{i}}}^{\mathrm{i}}$ & $0.84(3)$ & $1.99(3)$ & $2.822(2)$ & $170(3)$ \\
$\mathrm{O}^{\mathrm{W}} \mathrm{W}-\mathrm{H} 2 \mathrm{~W} \cdots \mathrm{O} 2^{\mathrm{ii}}$ & $0.83(3)$ & $1.88(3)$ & $2.692(2)$ & $165(3)$ \\
\hline
\end{tabular}

Symmetry codes: (i) $x+1, y, z$; (ii) $-x,-y+1,-z$

(a)
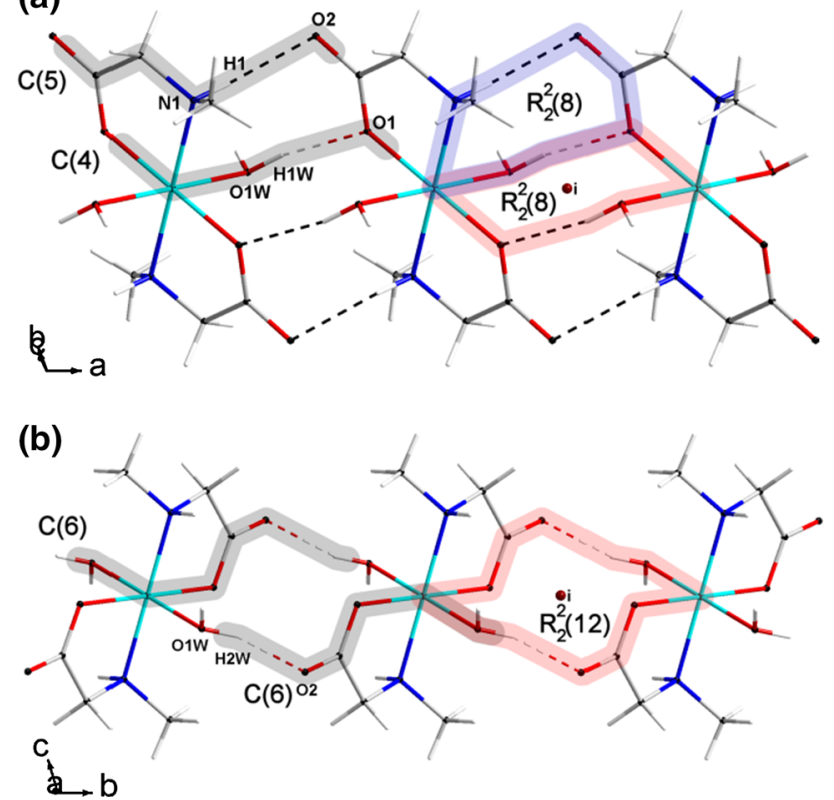

Fig. 4 a Chain and ring patterns of hydrogen bonds along (a) $a$ axis and $\mathbf{b} b$ direction

On the basis of $10 \mathrm{Dq}(\Delta)$ value obtained from solution spectra, sarcosine was located in the spectrochemical series of ligands for octahedral $\left[\mathrm{NiL}_{6}\right]$ or pseudooctahedral $\left[\mathrm{Ni}(\mathrm{L}-\mathrm{L})_{3}\right]$ complexes. This series is constructed based on the crystal field parameter $\Delta$ for $\mathrm{O}_{\mathrm{h}}$ symmetry and provides

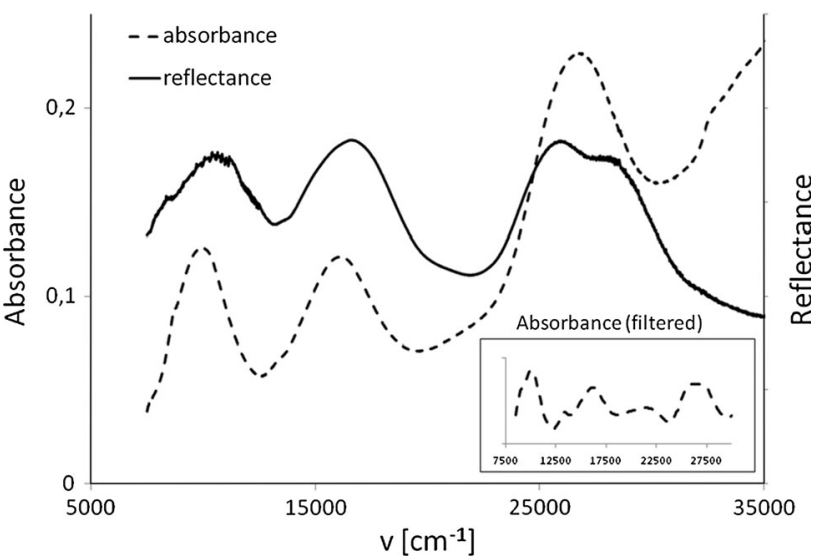

Fig. 5 Electronic spectra of $\left[\mathrm{Ni}(\mathrm{sar})_{2}\left(\mathrm{H}_{2} \mathrm{O}\right)_{2}\right]$ : reflectance (solid line) and absorbance in water solution (dashed line) as received and upon digital filtration (inset)

information about the strength of a ligand in the crystal field, i.e., its ability to split metal d levels in the electrostatic environment [46]. "Average environmental rule" [49] was applied in order to obtain the $\Delta$ value for hypothetical monoligand $\left[\mathrm{Ni}(\mathrm{sar})_{6}\right]^{4-}$ complex assuming exclusively monodentate $\mathrm{N}-\mathrm{Ni}$ coordination. $\Delta$ was calculated from the equation:

$\Delta\left[\mathrm{Ni}\left(\mathrm{H}_{2} \mathrm{O}\right)_{2} \mathrm{~L}_{4}\right]=1 / 6\left\{2 \Delta\left[\mathrm{Ni}\left(\mathrm{H}_{2} \mathrm{O}\right)_{6}\right]^{2+}+4 \Delta\left[\mathrm{NiL}_{6}\right]^{4-}\right\}$

Assuming $\Delta\left[\mathrm{Ni}\left(\mathrm{H}_{2} \mathrm{O}\right)_{6}\right]^{2+}=8500 \mathrm{~cm}^{-1} \quad$ [46] and $\Delta\left[\mathrm{Ni}\left(\mathrm{H}_{2} \mathrm{O}\right)_{2} \mathrm{~L}_{2}\right]=10,160 \mathrm{~cm}^{-1}$ (this work, Table 4), a hypothetical $\Delta\left[\mathrm{Ni}(\mathrm{sar})_{6}\right]^{4-}$ was found to be $10,990 \mathrm{~cm}^{-1}$. This value locates sarcosine ligand in the spectrochemical series as follows: $\mathrm{H}_{2} \mathrm{O}(8500)<$ py $(10,150)<\mathrm{NH}_{3}(10,750)$ $<1$-mhyd $\quad(10,750)<$ sar $\quad(\mathbf{1 0 , 9 9 0})<$ en $\quad(11,700)<$ bpy $(12,650)$.

Analysis of known crystal structures of sarcosine metal complexes (see Sect. 3, Fig. 2) indicates that bidentate coordination $\left[\mathrm{Ni}(\mathrm{sar})_{3}\right]^{-}$is more likely to occur. Moreover, sarcosine ligand in (1) is coordinated to $\mathrm{Ni}(\mathrm{II})$ ion with not only nitrogen atom (as it was assumed) but also with 
Table 4 Assigned transitions (in $\mathrm{cm}^{-1}$ ) on diffuse reflectance and absorbance in water solution $\left(C=6.9410^{-3} \mathrm{M}\right)$ spectra of $\left[\mathrm{Ni}(\mathrm{sar})_{2}\left(\mathrm{H}_{2} \mathrm{O}\right)_{2}\right], \varepsilon$ coefficient $\left(\mathrm{M}^{-1} \mathrm{~cm}^{-1}\right)$, crystal field (Dq, Dt, and Ds) and Racah B parameters

\begin{tabular}{llllll}
\hline Absorbance $\mathrm{O}_{\mathrm{h}}$ & & & & \multicolumn{2}{c}{ Reflectance $\mathrm{D}_{4 \mathrm{~h}}$} \\
\cline { 1 - 2 } \cline { 5 - 6 } \cline { 5 - 6 } & Filtered & $\varepsilon$ & & Filtered \\
\hline${ }^{3} \mathrm{~T}_{2 \mathrm{~g}}(\mathrm{~F})$ & 10,000 & 8.8 & ${ }^{3} \mathrm{E}_{\mathrm{g}}$ & 8500 \\
& & & ${ }^{3} \mathrm{~B}_{2 \mathrm{~g}}$ & 11,320 \\
${ }^{1} \mathrm{E}_{\mathrm{g}}(\mathrm{D})$ & 13,400 & - & ${ }^{1} \mathrm{~A}_{1 \mathrm{~g}}$ & 10,200 \\
& & & ${ }^{1} \mathrm{~B}_{1 \mathrm{~g}}$ & 12,500 \\
${ }^{3} \mathrm{~T}_{1 \mathrm{~g}}(\mathrm{~F})$ & 16,200 & 8.7 & ${ }^{3} \mathrm{~A}_{2 \mathrm{~g}}$ & 15,400 \\
& & & ${ }^{3} \mathrm{E}_{\mathrm{g}}$ & 17,000 \\
${ }^{3} \mathrm{~T}_{2 \mathrm{~g}}(\mathrm{D})$ & 21,400 & - & ${ }^{1} \mathrm{~B}_{2 \mathrm{~g}}$ & 21,000 \\
& & & ${ }^{1} \mathrm{E}_{\mathrm{g}}$ & \\
${ }^{3} \mathrm{~T}_{1 \mathrm{~g}}(\mathrm{P})$ & 26,200 & 16.5 & ${ }^{3} \mathrm{~A}_{2 \mathrm{~g}}$ & 25,600 \\
& & & ${ }^{3} \mathrm{E}_{\mathrm{g}}$ & 28,800 \\
CF and Racah parameters & & & & \\
$\mathrm{B}$ & 795 & & & 983 \\
$\beta$ & 0.76 & & & 0.94 \\
Dq & 1016 & & & 1132 \\
Dt & - & & & 239 \\
Ds & - & & & 1110 \\
\hline
\end{tabular}

(a)

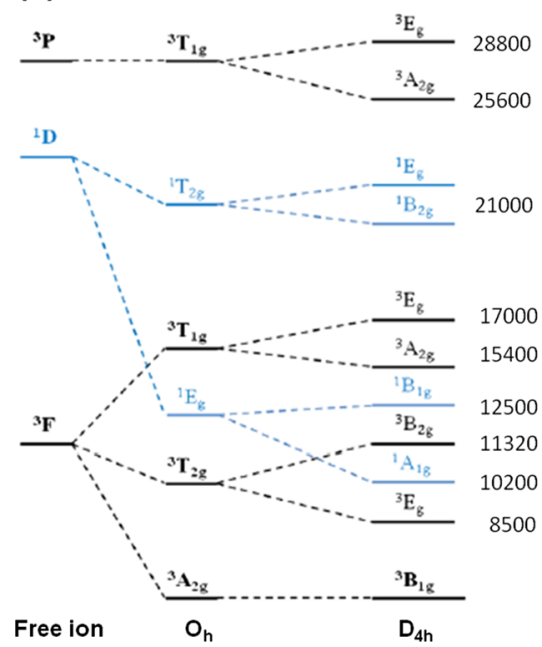

(b)

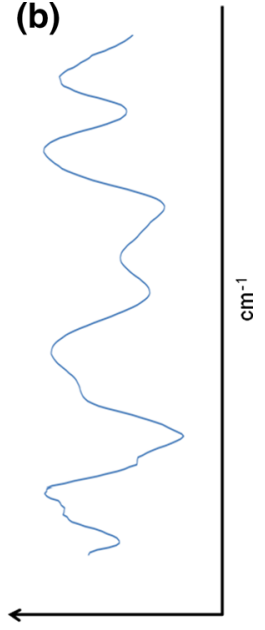

Fig. 6 a Correlation diagram $\left(d^{8}\right.$ configuration) for $O_{h}$ and $D_{4 h}$ symmetries and $\mathbf{b}$ the effect of filtration of the solid-state spectrum of $\left[\mathrm{Ni}(\mathrm{sar})_{2}\left(\mathrm{H}_{2} \mathrm{O}\right)_{2}\right]$

oxygen atom. Thus, the position of sarcosine in this row should be treated tentatively.

\section{Geometry and charge distribution}

The studied complex is an open-shell system, $\mathrm{d}^{8}$ electron configuration of $\mathrm{Ni}(\mathrm{II})$ cation with an pseudooctahedral
Table 5 Natural charge (e) on selected atoms of $\left[\mathrm{Ni}(\mathrm{sar})_{2}\left(\mathrm{H}_{2} \mathrm{O}\right)_{2}\right]$ calculated at the DFT/PBE0 level

\begin{tabular}{llllllll}
\hline $\mathrm{Ni}$ & $\mathrm{O} 1$ & $\mathrm{~N} 1$ & $\mathrm{C} 1$ & $\mathrm{O} 2$ & $\mathrm{C} 2$ & $\mathrm{C} 3$ & $\mathrm{O} 1 \mathrm{w}$ \\
\hline 1.41 & -0.92 & -0.78 & 0.88 & -0.68 & -0.34 & -0.41 & -1.02 \\
\hline
\end{tabular}

environment of ligand donor atoms, which required the use of the unrestricted methods for the calculations of an electronic structure. The molecular parameters predicted for (1) are in good agreement with the X-ray diffraction results (Table 2). The calculated metal-ligand distances are equal to 2.002 (Ni1-O1), $2.224 \AA$ (Ni1-O1 W), and $2.081 \AA(\mathrm{Ni} 1-\mathrm{N} 1)$.

According to the NBO results, the electronic configuration of $\mathrm{Ni}$ is [core] $4 \mathrm{~s}(0.25) 3 \mathrm{~d}(8.32) 4 \mathrm{p}(0.02)$ : 18 core electrons, 8.59 valence electrons (on $4 \mathrm{~s}$ and $3 \mathrm{~d}$ atomic orbitals), and 0.02 Rydberg electrons, mainly on the $4 p$ orbital. This gives the total number of 26.59 electrons, which is consistent with the calculated natural charge $(+1.41)$ on the $\mathrm{Ni}$ atom in (1). The calculated natural charges on the atoms are collected in Table 5.

\section{Vibrational spectra}

The selected experimental and theoretical frequencies, IR intensities, and Raman intensities are shown in Table 6. All the experimental and calculated frequencies are listed in Table S1 of the Supporting Information. Figure 7 shows the experimental Raman and IR vibrational spectra of (1) in the range $4000-500 \mathrm{~cm}^{-1}$.

In the experimental Raman spectrum, the strong band is observed at $3247 \mathrm{~cm}^{-1}$. According to the PED calculation, this band is due to stretching vibration of $\mathrm{NH}$ group of sarcosine ligands. The subsequent Raman bands of strong intensities were assigned to the $\mathrm{CH}$ stretching of methyl and methylene groups of organic ligands. The characteristic band of symmetric $\mathrm{CH}$ stretching vibrations of $\mathrm{N}-\mathrm{CH}_{3}$ group is observed at $2814 \mathrm{~cm}^{-1}$ in experimental Raman and IR spectra.

The characteristic band due to $\mathrm{C}=\mathrm{O}$ stretching is observed at $1607 \mathrm{~cm}^{-1}$ in the experimental IR spectrum. This assignment is supported by the predicted large IR intensity of the mode 18 .

According to the PED calculation, the strong band at $1397 \mathrm{~cm}^{-1}$ is associated with $\mathrm{C}-\mathrm{O}$ stretching vibration. The separation of the bands due to $\mathrm{CO}$ stretching of carboxylic groups denoted as $v_{\mathrm{as}}\left(\mathrm{COO}^{-}\right)$and $v_{\mathrm{s}}\left(\mathrm{COO}^{-}\right)$over $200 \mathrm{~cm}^{-1}$ is consistent with monodentate manner of the coordination of sarcosine carboxylic group to the nickel ion.

The next strong IR band at $1320 \mathrm{~cm}^{-1}$ was assigned to the mode 33 with predominant contribution (66\%) from bending deformation of the $\mathrm{CH}_{2}$ groups. 


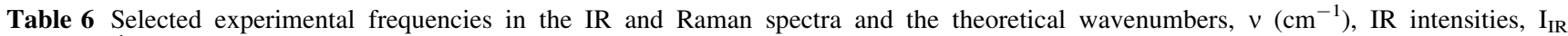
$\left(\mathrm{km} \mathrm{mol}^{-1}\right), \mathrm{I}_{\mathrm{R}}$ Raman intensities (arbitrary units) of $\left[\mathrm{Ni}(\mathrm{sar})_{2}\left(\mathrm{H}_{2} \mathrm{O}\right)_{2}\right]$ calculated at the PBE0 density functional

\begin{tabular}{|c|c|c|c|c|c|c|c|}
\hline \multirow[t]{2}{*}{ No. } & \multicolumn{2}{|l|}{ Exp. } & \multicolumn{5}{|c|}{ Theor. } \\
\hline & IR & Raman & sym & $v^{\mathrm{a}}$ & $I_{\mathrm{IR}}$ & $I_{\mathrm{R}}$ & Band assignment, PED $(\%)^{\mathrm{b}}$ \\
\hline 6 & & 3247 vs & $\mathrm{A}_{\mathrm{g}}$ & 3357 & 0.0 & 30.8 & $v_{\mathrm{s}} \mathrm{NH}(100)$ \\
\hline 8 & & $3008 \mathrm{~s}$ & $\mathrm{~A}_{\mathrm{g}}$ & 3012 & 0.0 & 30.6 & $v_{\mathrm{a}}^{\mathrm{I}} \mathrm{CH}_{3}(100)$ \\
\hline 10 & & $2979 \mathrm{~s}$ & $A_{g}$ & 2978 & 0.0 & 36.2 & $v_{\mathrm{a}}^{\mathrm{II}} \mathrm{CH}_{3}(96)$ \\
\hline 13 & & 2926 vs & $\mathrm{A}_{\mathrm{g}}$ & 2915 & 0.0 & 122.4 & $v_{\mathrm{s}} \mathrm{CH}_{2}(100)$ \\
\hline 14 & $2926 \mathrm{~m}$ & & $\mathrm{~A}_{\mathrm{u}}$ & 2915 & 37.8 & 0.0 & $v_{\mathrm{s}} \mathrm{CH}_{2}(100)$ \\
\hline 15 & & $2815 \mathrm{~m}$ & $\mathrm{~A}_{\mathrm{g}}$ & 2885 & 0.0 & 157.0 & $v_{\mathrm{s}} \mathrm{CH}_{3}(96)$ \\
\hline 16 & $2814 \mathrm{w}$ & & $\mathrm{A}_{\mathrm{u}}$ & 2885 & 98.2 & 0.0 & $v_{\mathrm{s}} \mathrm{CH}_{3}(96)$ \\
\hline 17 & & $1580 \mathrm{w}$ & $A_{g}$ & 1605 & 0.0 & 46.4 & $v_{\mathrm{s}} \mathrm{C}=\mathrm{O}(83), v_{\mathrm{s}} \mathrm{C}-\mathrm{O}(11)$ \\
\hline 18 & 1607 vs & & $\mathrm{A}_{\mathrm{u}}$ & 1598 & 1321.5 & 0.0 & $v_{\mathrm{a}} \mathrm{C}=\mathrm{O}(83), v_{\mathrm{a}} \mathrm{C}-\mathrm{O}(10)$ \\
\hline 32 & $1397 \mathrm{vs}$ & & $\mathrm{A}_{\mathrm{u}}$ & 1380 & 550.4 & 0.0 & $v_{\mathrm{a}} \mathrm{C}-\mathrm{O}(48), v_{\mathrm{a}} \mathrm{CC}(19)$, twistCH$_{2}$ (12) \\
\hline 33 & 1320 vs & & $\mathrm{A}_{\mathrm{u}}$ & 1327 & 83.9 & 0.0 & twistCH ${ }_{2}(66), v_{\mathrm{a}} \mathrm{C}-\mathrm{O}(16)$ \\
\hline 41 & $1100 \mathrm{~s}$ & & $\mathrm{~A}_{\mathrm{u}}$ & 1138 & 48.3 & 0.0 & $v_{\mathrm{a}} \mathrm{N}-\mathrm{CH}_{3}(41), \rho_{\mathrm{r}} \mathrm{CH}_{3}(22), v_{\mathrm{a}} \mathrm{CN}(16)$ \\
\hline 42 & & $1098 \mathrm{~m}$ & $A_{g}$ & 1137 & 0.0 & 38.0 & $v_{\mathrm{s}} \mathrm{N}-\mathrm{CH}_{3}(42), \rho_{\mathrm{r}} \mathrm{CH}_{3}(21), v_{\mathrm{s}} \mathrm{CN}(16)$ \\
\hline 49 & $927 \mathrm{~m}$ & & $\mathrm{~A}_{\mathrm{u}}$ & 936 & 87.5 & 0.0 & $v_{\mathrm{a}} \mathrm{CC}(39), v_{\mathrm{a}} \mathrm{C}-\mathrm{O}(18), \delta \mathrm{C}=\mathrm{O}(16)$ \\
\hline 50 & & $928 \mathrm{w}$ & $\mathrm{A}_{\mathrm{g}}$ & 935 & 0.0 & 35.7 & $v_{\mathrm{s}} \mathrm{CC}(43), v_{\mathrm{s}} \mathrm{C}-\mathrm{O}(18), \delta \mathrm{C}=\mathrm{O}(16)$ \\
\hline 51 & 732 vs & & $\mathrm{A}_{\mathrm{u}}$ & 745 & 94.6 & 0.0 & $\delta$ Ring (35), $\rho_{\mathrm{r}} \mathrm{H}_{2} \mathrm{O}(18), \delta \mathrm{C}=\mathrm{O}$ \\
\hline 61 & $445 \mathrm{~m}$ & & $\mathrm{~A}_{\mathrm{u}}$ & 446 & 102.8 & 0.0 & $v_{\mathrm{a}} \mathrm{NiN}(26), v_{\mathrm{a}} \mathrm{NiO}(24), \tau \mathrm{H}_{2} \mathrm{O}(12), \delta \mathrm{H}-\mathrm{N}-\mathrm{CH}_{3}(10)$ \\
\hline 62 & & $442 \mathrm{~m}$ & $\mathrm{~A}_{\mathrm{g}}$ & 423 & 0.0 & 176.3 & $v_{\mathrm{s}} \mathrm{NiN}(27), v_{\mathrm{s}} \mathrm{NiO}(25), \delta \mathrm{H}-\mathrm{N}-\mathrm{CH}_{3}(10)$ \\
\hline 67 & $315 \mathrm{~m}$ & & $\mathrm{~A}_{\mathrm{u}}$ & 336 & 15.3 & 0.0 & $v_{\mathrm{a}} \mathrm{NiO}(41), \delta \mathrm{H}-\mathrm{N}-\mathrm{CH}_{3}(13), \delta \mathrm{C}=\mathrm{O}(12), v_{\mathrm{a}} \mathrm{NiN}(11)$ \\
\hline 68 & $292 \mathrm{~m}$ & & $\mathrm{~A}_{\mathrm{u}}$ & 314 & 15.8 & 0.0 & $\delta$ Ring (75) \\
\hline 69 & & 299 vw & $\mathrm{A}_{\mathrm{g}}$ & 290 & 0.0 & 9.2 & $v_{\mathrm{s}} \mathrm{NiO}(31), \delta \mathrm{H}-\mathrm{N}-\mathrm{CH}_{3}(24), v_{\mathrm{s}} \mathrm{NiN}(22), \delta \mathrm{C}=\mathrm{O}(12)$ \\
\hline 70 & $252 \mathrm{~m}$ & & $\mathrm{~A}_{\mathrm{u}}$ & 261 & 30.9 & 0.0 & $v_{\mathrm{a}} \mathrm{Ni}-\mathrm{OH}_{2}(24), \tau \mathrm{CH}_{3}(40), \delta \mathrm{H}-\mathrm{N}-\mathrm{CH}_{3}(10)$ \\
\hline 71 & & $228 \mathrm{~m}$ & $\mathrm{~A}_{\mathrm{g}}$ & 253 & 0.0 & 52.1 & $v_{\mathrm{s}} \mathrm{Ni}-\mathrm{OH}_{2}(42), \tau \mathrm{CH}_{3}(20), \delta$ Ring (18) \\
\hline 76 & & $185 \mathrm{~s}$ & $\mathrm{~A}_{\mathrm{g}}$ & 199 & 0.0 & 79.1 & $v_{\mathrm{s}} \mathrm{NiO}(34), v_{\mathrm{s}} \mathrm{Ni}-\mathrm{OH}_{2}(21), \delta \mathrm{Ring}(16), \delta \mathrm{H}-\mathrm{N}-\mathrm{CH}_{3}(10)$ \\
\hline
\end{tabular}

$b r$ Broad, $m$ medium, $s$ strong, $s h$ shoulder, $w$ weak, $v$ very, $v$ stretching, $\delta$ in-plane bending or $\mathrm{CH}_{3}$ deformation, $\gamma$ out-of-plane bending, $\rho_{r}$ rocking, $\tau$ torsion. Subscripts $a$ antisymmetric, $s$ symmetric

${ }^{\text {a }}$ Two scaling factors for the calculated harmonic frequencies have been used: 0.942 for modes $1-16$ and 19, $20 ; 0.88$ for modes $17+18$. Other calculated frequencies are left unscaled

b The predominant components of the PED matrix or their linear combinations (e.g., stretching or bending of the coordination ring)

The experimental Raman and IR spectra in the range of $500-100 \mathrm{~cm}^{-1}$ are presented in Fig. 8. As revealed by the PED calculation, the nickel-ligand vibrations are mixed with each other and also with different bending deformation of coordination rings of two sarcosine ligands. According to the calculated theoretical wave numbers, IR and Raman intensities, the bands due to vibrations with predominant contribution from $v(\mathrm{Ni}-\mathrm{O})$ and $v(\mathrm{Ni}-\mathrm{N})$ stretchings are observed at $445 \mathrm{~cm}^{-1}$ (IR) and $442 \mathrm{~cm}^{-1}$ (Raman).

\section{Summary and conclusions}

Sarcosine complex $\left[\mathrm{Ni}(\mathrm{sar})_{2}\left(\mathrm{H}_{2} \mathrm{O}\right)_{2}\right]$ was obtained by a novel route-as an unexpected solid product of the system: [Ni(II)-1-methylhydantoin]. Sarcosine was generated through basic hydrolysis of 1-methylhydantoin and was coordinated in situ to the metal ion. To the best of our knowledge, this is the first example of the sarcosine complex synthesis, which starts from a substrate other than sarcosine itself. Moreover, the crystals of the complex are of better quality than those obtained with the traditional method. Although the compound was known earlier, the hydrogen bond analysis and spectroscopic (IR, Raman, and NIR-UV-Vis) studies combined with DFT calculations presented here allowed for its better characterization. Single crystal X-ray diffraction revealed that adjacent molecules are bound by H-bonds. It leads to the formation of a $2 \mathrm{D}$ network, created by two chain patterns along the main crystallographic directions $a$ and $b$. Solid-state reflectance electronic spectrum strengthened by digital filtration proved that geometry of the nickel(II) surrounding can be described as tetragonal. However, in water 

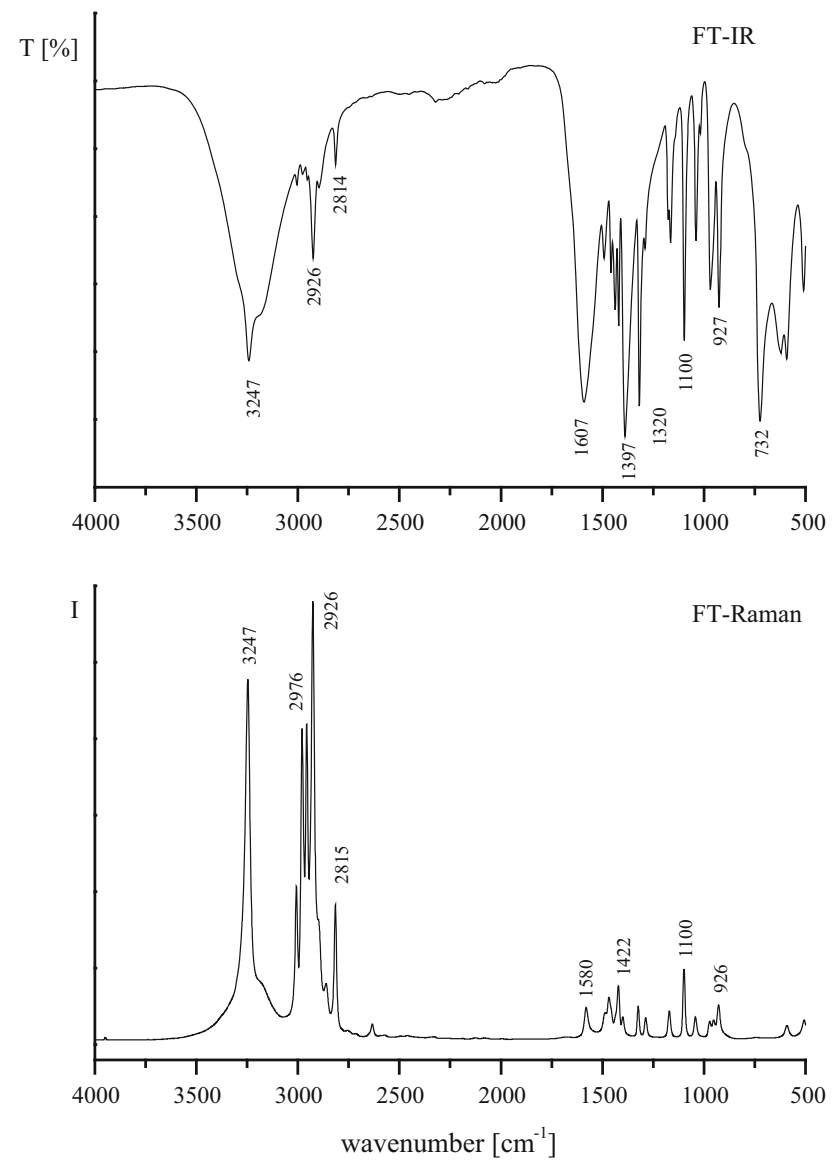

Fig. 7 Experimental FT-IR and FT-Raman spectra in the range of $4000-500 \mathrm{~cm}^{-1}$

solution, the complex exhibits higher, pseudooctahedral symmetry. Crystal field and Racah B parameters were calculated for both tetragonal and pseudooctahedral geometries. Comparison of nephelauxetic parameters calculated for (1) in solid state and solution shows that $\mathrm{M}-\mathrm{L}$ bonds have a more ionic nature in the solid state than in the water solution. By application of the "average environment rule," sarcosine was tentatively ranked in the spectrochemical series of ligands. The obtained $10 \mathrm{Dq}$ value of $10,990 \mathrm{~cm}^{-1}$ located sarcosine between ammonia and 1-methylhydantoin. It means that this amino acid has moderately strong splitting ability.

The PED analysis revealed that carboxylic groups of sarcosine ligands show a monodentate mode of coordination to the nickel atom. The presence of the Ni1-N1 and Ni1-O1 bands in the vibrational spectra of the studied complex is consistent with the presence of the chelating rings formed during coordination of nickel by sarcosine ligands.

Acknowledgments The authors are grateful to Dr. Mariola Puszyńska-Tuszkanow for her helpful advice during the practical part of this work. Mrs. Elżbieta Mróź and M.Sc. Magdalena Malik are
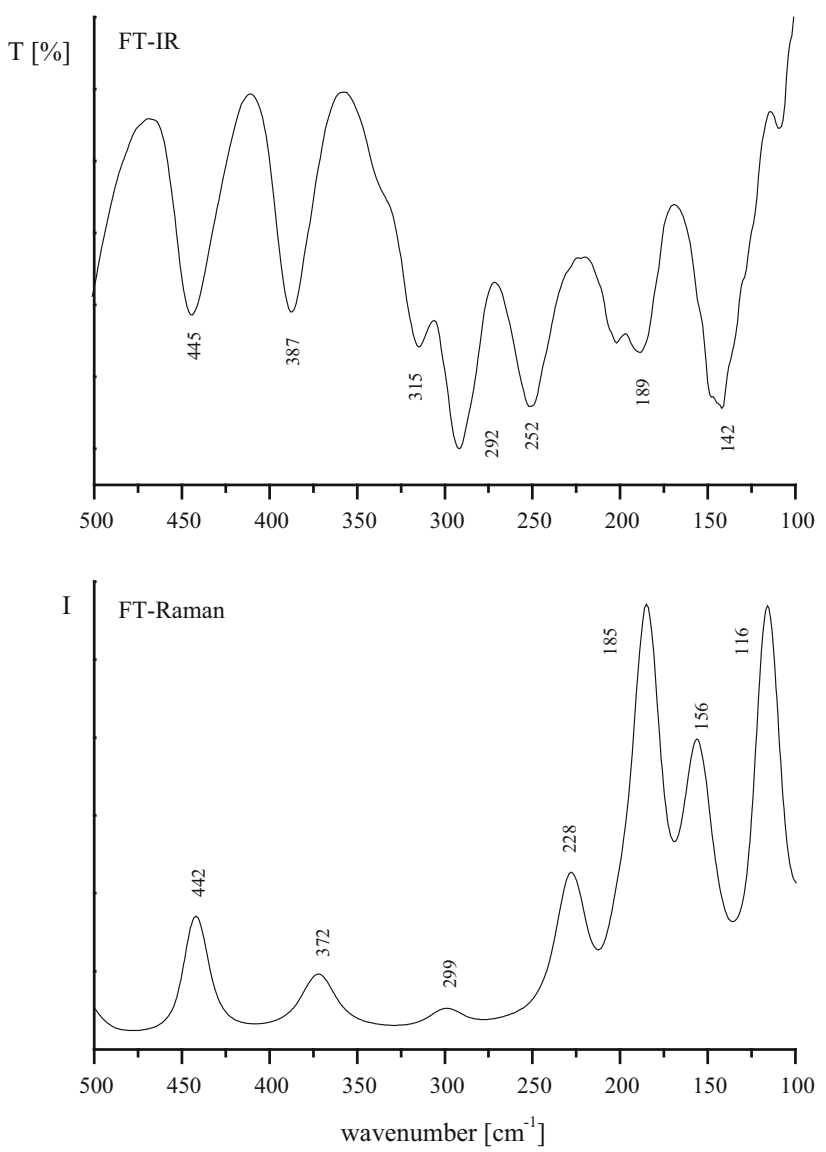

Fig. 8 Experimental FT-IR and FT-Raman spectra in the range of $500-100 \mathrm{~cm}^{-1}$

acknowledged for their measurements of the IR and Raman spectra, respectively. This work was financed in part by a statutory activity subsidy from the Polish Ministry of Science and Higher Education for the Faculty of Chemistry of Wroclaw University of Technology. The generous computer time from the Wroclaw Supercomputer and Networking Center and the Poznan Supercomputer and Networking Center is acknowledged.

Open Access This article is distributed under the terms of the Creative Commons Attribution 4.0 International License (http://crea tivecommons.org/licenses/by/4.0/), which permits unrestricted use, distribution, and reproduction in any medium, provided you give appropriate credit to the original author(s) and the source, provide a link to the Creative Commons license, and indicate if changes were made.

\section{References}

1. Mudd SH, Ebert MH, Scriver CR (1980) Metabolism 29:707

2. Katz E, Goss WA (1959) Biochem J Nov 73:458

3. Lloyd AW, Baker JA, Smith G, Olliff CJ, Rutt KJ (1992) J Pharm Pharmacol 44:507

4. Strzelecki D, Szyburska J, Rabe-Jabłońska J (2014) Neuropsych Dis Treat 10:263

5. Ashida T, Bando S, Kakudo M (1972) Acta Cryst B28:1560

6. Krishnakumar RV, Natarajan S (1995) Cryst Res Technol 30:825 
7. Krishnakumar RV, Subha Nadhini M, Natarajan S (2001) Acta Cryst 57:192

8. Gawryszewska PP, Jerzykiewicz L, Sobota P, Legendziewicz J (2000) J Alloys Compd 300:275

9. Sabo TJ, Dinović VM, Kaluderović GN, Stanojković TP, Bogdanović GA, Juranić ZD (2005) Inorg Chim Acta 358:2239

10. Puszyńska-Tuszkanow M, Daszkiewicz M, Maciejewska G, Adach A, Cieślak-Golonka M (2010) Struct Chem 21:315

11. Puszyńska-Tuszkanow M, Daszkiewicz M, Maciejewska G, Staszak Z, Wietrzyk J, Filip B, Cieślak-Golonka M (2011) Polyhedron 30:2016

12. Puszyńska-Tuszkanow M, Grabowski T, Daszkiewicz M, Wietrzyk J, Filip B, Maciejewska G, Cieślak-Golonka M (2011) J Inorg Biochem 105:17

13. Puszyńska-Tuszkanow M, Staszak Z, Misiaszek T, Klepka MT, Wolska A, Drzewiecka-Antonik A, Fałtynowicz H, CieślakGolonka M (2014) Chem Phys Lett 597:94

14. Ware E (1950) Chem Rev 46:403

15. Puszyńska-Tuszkanow M, Daszkiewicz M, Maciejewska G, Cieślak-Golonka M (2009) Inorg Chem Commun 12:484

16. Guha S (1973) Acta Cryst B29:2167

17. Sheldrick GM (2008) Acta Cryst A64:112

18. Hübschle CB, Sheldrick GM, Dittrich B (2011) J Appl Cryst 44:1281

19. Biermann G, Ziegler H (1986) Anal Chem 58:536

20. Myrczek J (1990) Spectr Lett 23:1027

21. Underhill AE, Billing DE (1966) Nature 210:834

22. Bartecki A, Kurzak K (1981) Bull de L'Academie Polonaise des Sci 29:299

23. Perdew JP, Burke K, Ernzerhof M (1996) Phys Rev Lett 77:3865

24. Ernzerhof M, Scuseria GE (1999) J Chem Phys 110:5029

25. Adamo C, Barone V (1999) J Chem Phys 110:6158

26. Hay PJ, Wadt WR (1985) J Chem Phys 82:270

27. Menon AS, Radom L (2008) J Phys Chem A 112:13225

28. Frisch MJ, Trucks GW, Schlegel HB, Scuseria GE, Robb MA, Cheeseman JR, Scalmani G, Barone V, Mennucci B, Petersson GA, Nakatsuji H, Caricato M, Li X, Hratchian HP, Izmaylov AF, Bloino J, Zheng G, Sonnenberg JL, Hada M, Ehara M, Toyota K, Fukuda R, Hasegawa J, Ishida M, Nakajima T, Honda Y, Kitao O, Nakai H, Vreven T, Montgomery JA Jr., Peralta JE, Ogliaro F, Bearpark M, Heyd JJ, Brothers E, Kudin KN, Staroverov VN, Kobayashi R, Normand J, Raghavachari K, Rendell A, Burant JC, Iyengar SS, Tomasi J, Cossi M, Rega N, Millam JM, Klene M, Knox JE, Cross JB, Bakken V, Adamo C, Jaramillo J, Gomperts
R, Stratmann RE, Yazyev O, Austin AJ, Cammi R, Pomelli C, Ochterski JW, Martin RL, Morokuma K, Zakrzewski VG, Voth GA, Salvador P, Dannenberg JJ, Dapprich S, Daniels AD, Farkas Ö, Foresman JB, Ortiz JV, Cioslowski J, Fox DJ (2009) Gaussian Inc., Wallingford CT

29. Reed AE, Curtiss LA, Reinhold F (1988) Chem Rev 88:899

30. Glendening ED, Badenhoop JK, Reed AE, Carpenter JE, Bohmann JA, Morales CM, Weinhold F (2001) NBO 5.0 software. Theoretical Chemistry Institute, University of Wisconsin, Madison

31. Nowak MJ, Lapinski L, Bieńko DC, Michalska D (1997) Spectrochim Acta A 53:855

32. Rostkowska H, Lapinski L, Nowak MJ (2009) Vib Spectrosc 49:43

33. Fogarasi G, Zhou X, Taylor PW, Pulay P (1992) J Am Chem Soc 114:8191

34. Lapinski L., Nowak M.J., unpublished computer program BALGA for PED calculations

35. Polavarapu PL (1990) J Phys Chem 94:8106

36. Keresztury G, Holly S, Besenyei G, Varga J, Aiying Wang, Durig JR (1993) Spectrochim Acta A 49:2007

37. Michalska D, Wysokiński R (2005) Chem Phys Lett 403:211

38. Krishnakumar RV, Natarajan S, Bahadur SA, Cameron TS (1994) Z Kristallogr 209:443

39. Inomata Y, Shibata A, Yukawa Y, Takeuchi T, Moriwaki T (1988) Spectrochim Acta A 44:97

40. Larsen S, Watson KJ, Sargeson KM, Turnbull KR (1968) Chem Commun 15:847

41. Trzebiatowska-Gusowska M, Gągor A, Baran J, Drozd M (2009) J Raman Spectrosc 40:315

42. Silva MR, Beja AM, Paixao JA, de Veiga LA (2001) Z Kristallogr New Cryst Struct 216:419

43. Fleck M, Ghazaryan VV, Petrosyan AM (2013) Acta Cryst C69:11

44. Etter MC, MacDonald JC, Bernstein J (1990) Acta Cryst B46:256

45. Daszkiewicz M (2012) Struct Chem 23:307

46. Lever ABP (1984) Inorganic Electronic Spectroscopy. Elsevier, New York

47. König E (1971) Struct Bond 9:175

48. Małecki JG, Mroziński J, Michalik K (2011) Polyhedron 30:1806

49. Lever ABP, Nelson SM, Shepherd TM (1965) Inorg Chem 4:810 